\title{
Prevalence of cagA and babA2 positive Helicobacter pylori strains in dyspeptic patients in Iran
}

\author{
Mahsa Esmaeillu ${ }^{1 *}$, Ali Bahadori², Mehmet Agin ${ }^{3}$, Melda Meral $^{2}$ \\ ${ }^{1}$ Department of Microbiology, University of Tabriz, Faculty of Natural Sciences, Tabriz, Iran. \\ ${ }^{2}$ Department of Medical Microbiology, Faculty of Medicine, Cukurova University, Adana, Turkey. \\ ${ }^{3}$ Department of Pediatric Gastroenterology, Cukurova University Medical Faculty, Adana, Turkey.
}

\begin{abstract}
Background: Helicobacter pylori genome encodes a large number of virulence and adhesion factors that involved in bacterial adhesion to host cells and exerts its virulence effect with CagA secretion. In this study, we aimed to examine the relationships between $b a b A 2$ and cagA genotype and presence of gastric disorders in patients from Iran.

Material and Methods: The presence of $H$. pylori and selected genes (cagA and babA2) were detected by PCR method from the genomic DNA of 105 patients who had been diagnosed with gastric disorders like chronic gastritis by endoscopic and histopathologic routes.

Results: Presence of H. pylori (glmM gene) was detected in 85 out of 105 (80.9\%) patients. According to our results cagA gene was found in 66 out of 85 (77.6\%) patients and babA2 gene was found in 80 out of 85 (94.1\%) patient.

Conclusion: In conclusion, the cagA and $b a b A 2$ genotypes might be considered as useful biomarkers for non-ulcer disease (NUD) patients and gastric disorders in the geographic region of Iran and the presence of $H$. pylori strains with double-positive status is high clinical relevance to $H$. pylori-associated diseases.
\end{abstract}

Key words: Helicobacter pylori, babA2, cagA, gastric disorders.

\section{Introduction}

Less than three decades ago, Robin Warren and Barry Marshall definitively identified Helicobacter pylori by culturing an organism from gastric biopsy specimens that had been visualized for almost a century by pathologists (1). H. pylori is a gram-negative spiral organism that is capable of colonizing the gastric mucosa and form the main cause of chronic active gastritis (2). Colonization with $H$. pylori is the commonest infection worldwide, affecting at least half the world's population (3). Adherence of $H$. pylori to the gastric epithelium facilitates initial colonization, persistence of infection, and delivery of virulence factors to host epithelial cells.

*Corresponding Author: Department of Biology, Faculty of Biological Sciences, University of Tabriz, Tabriz-Iran. Phone: +989381634208 E-mail: M_esmaeillu92@ms.tabrizu.ac.ir Received: Apr 18, 2016 Accepted: Apr 27, 2016 Published Online: May 21, 2016.
The cytotoxin-associated gene $(\operatorname{cag} A)$ was the first gene found to be differentially present in $H$. pylori isolates and is considered a marker for the presence of the cag pathogenicity island cagPAI. H. pylori strains can be divided into CagA positive or negative strains. CagA was identified as the first protein of the cagPAI and appeared to be a major virulence factor (4). CagA is an oncoprotein that thought to be involved in cancer development. The recently described blood group antigen-binding adhesin BabA has been shown to mediate adherence of $H$. pylori to Lewis b receptors on gastric epithelium (4).

This is an Open Access article distributed under the terms of the Creative Commons Attribution Non-Commercial License (http://creativecommons.org/licenses/bync/4.0/) which permits unrestricted non-commercial use, distribution, and reproduction in any medium, provided the original work is properly cited. 
Albeit three bab alleles have been recognized (babA1, babA2, and babB), only the babA2 gene product is intransitive blood-group antigen-binding adhesin that mediates attachment of $H$. pylori to human Lewis-b antigens $(5,6)$. In this investigation, we focused on $H$. pylori BabA2 adhesion factor and CagA virulence factor in patients suffering from chronic gastritis. We sought to examine the relationships between babA2 and cagA genotypes in patients with gastrointestinal disorders and identify the independent markers of non-ulcer disease (NUD) such as dyspepsia and chronic gastritis in patients from Iran.

\section{Material and methods}

\section{Sample collection}

In this study, a total of 105 biopsy samples from the stomach antrum and corpus were obtained from patients with gastro duodenal disorders like chronic gastritis, dyspepsia and non-ulcer disease (NUD) that, referred to endoscopy department of Imam Reza hospital, Tabriz, Iran. For study the babA2 and cagA genes, PCR method was used. To PCR analysis DNA was extracted from obtained biopsy samples by performing QIAamp DNA Mini Kit (Qiagen Inc., Germany), according to the manufacturer's instructions and prepared DNA were stored at $-20{ }^{\circ} \mathrm{C}$ for using in future studies.

\section{PCR analysis}

The $\operatorname{glm} M$ gene was primarily amplified for detection of H. pylori DNA in collected samples. The forward primer (5'-AAG CTT TTA GGG GTG TTA GGG GTT T-3') and the reverse primer $\left(5^{\prime}\right.$-AAG CTT ACT TTC TAA CAC TAA CGC-3' ) were derived from the published "H. pylori" glmM (Urea C) sequence and used to amplify a 294-bp segment of $H$. pylori urease $C$ gene (7). PCR analyses were carried out to determine the presence or absence of cagA and babA2 genes in each $H$. pylori positive sample by using specific primers. The sequences of these primers are described in (Table 1).

The amplification reaction consisted of 1 to $2 \mu \mathrm{l}$ DNA samples in a final volume of $50 \mu$ containing $1 \times$ PCR buffer, $200 \mu \mathrm{M}$ (each) deoxy nucleoside triphosphate, 100 pmol of primers and 2.5 U of Taq DNA polymerase in Thermo cycler (MJ Mini BIO-RAD).

For analysis of the amplified products of each PCR assay, $6 \mu \mathrm{l}$ of the amplicons were electrophoresed with a $1 \mathrm{X}$
tris-acetate-EDTA buffer on $2 \%$ agarose gel stained by ethidium bromide $(5 \mu \mathrm{l} / 100 \mathrm{ml})$. The amplicons were visualized by UV transillumination, and a 100 base pair ladder was used as standard.

The statistical analysis of data was accomplished by using logistic regression, chi-square test with significance set at a $P$ value of $<0.05$.

\section{Results}

From all of 105 patients, H. pylori (presence of glmM gene) were detected in 85 patients $(80.9 \%)$ including 44 (41.90\%) men and $61(58.09 \%)$ women with mean age of 53 years old $( \pm 30.5)$. Age, sex, and PCR findings of patients were tabulated and analyzed by Matlab and SPSS 14 statistical package. In our study cagA and babA2 genes were found in $77.6 \%$ and $94.1 \%$ of $H$. pylori positive samples respectively. The prevalence of cagA and babA2 harboring strains in Iran is similar. The results of this study suggest that, in Iran like some other countries the presence of cagA and $b a b A 2$ positive $H$. pylori strains is associated with $H$. pylori related diseases such as dyspepsia, NUD and chronic gastritis (Table2).

Table 1. Description of the pairs of primers used in the amplification of $\operatorname{cag} A$ and $b a b A 2$ genes.

\begin{tabular}{lll}
\hline $\begin{array}{l}\text { Gene/ } \\
\text { Primers }\end{array}$ & Sequence & $\begin{array}{l}\text { Size/ } \\
\text { (References) }\end{array}$ \\
\hline $\boldsymbol{g l m \boldsymbol { M }}$ & F 5'-AGCTTTTAGGGGTGT & 294 bp \\
& TAGGGGTTT-3' & $(7)$ \\
& R 5'-AAGCTTACTTTCT & \\
& AACACTAACGC-3' & \\
$\boldsymbol{c a g} \boldsymbol{A}$ & F 5'-GATAACAGGCAA & $349 \mathrm{bp}$ \\
& GCTTTTGAGG-3 & $(7,16)$ \\
& R 5'-CTGCAAAAGATT & \\
& GTTTGGCAGA-3' & \\
$\boldsymbol{b a b A 2}$ & F 5'-AATCCAAAAAG & $832 \mathrm{bp}$ \\
& GAGAAAAAGTATGAAA-3' & $(15)$ \\
& R 5'-TGTTAGTGATTTCG & \\
& GTGTAGGAC-3' & \\
\hline
\end{tabular}

Table 2. The statistical analysis and frequency of babA2 and $\operatorname{cag} A$ positive $H$. pylori strains.

\begin{tabular}{llll}
\hline Genotype & NUD n $(\%)$ & $\chi^{2}$ & $\boldsymbol{p}$ value \\
\hline babA2 positive & $80 / 85(94.11)$ & 9.509 & 0.0020 \\
$\boldsymbol{c a g A}$ positive & $66 / 85(77.64)$ & & \\
\hline
\end{tabular}




\section{Discussion}

In the study of infectious diseases, researchers for recognize a real pathogen from innocuous organisms, often focus on bacterial virulence factors. Since the discovery of Helicobacter pylori, many investigations have focused on explaining the microorganism pathogenicity mechanisms that are associated with disease outcome. In studies conducted on $H$. pylori, several virulence factors have been discussed. But one of the most critical property of $H$. pylori, is its ability to remain for many years within the host tissues without any damage. Therefore, colonization is not equivalent with virulence but rather may refer to the persistence of the microorganism in a specific site in the host. The adherence of $H$. pylori to host cells is a pertinent step in the development of gastro duodenal disorders. In our study, we focused on $H$. pylori BabA2 adhesion factor and CagA virulence factor in patients suffer from gastro duodenal disorders like chronic gastritis and dyspepsia. In our study cagA and $b a b A 2$ genes were found in $77.6 \%$ and $94.1 \%$ of $H$. pylori positive samples respectively. The prevalence of $\operatorname{cag} A$ and $b a b A 2$ harboring strains in Iran is similar.

In studies of $H$. pylori colonization and its adhesion to the host cells, the BabA adhesion has been the most studied factor $(8,9)$. BabA2 attaches $H$. pylori to host epithelial cells, permitting the transfer of CagA toxin to the gastric epithelium and so increasing gastric tissue damage. Some authors suggest that, the presence of babA2 is associated with some disorders like duodenal ulcer and gastric cancer, when found in conjunction with vacA s 1 alleles and cagA (10). In our study cagA gene was found in $77.6 \%$ of patients with $H$. pylori and babA2 genotype was positive in $94.1 \%$ of patients, we also showed that, the co-presence of these genes can increase the risk of gastro duodenal disorders. The last analyses of babA2 gene as a marker for diagnosis $H$. pylori associated disease have produced inconsistent data on the useless of this gene expression in anticipating clinical outcomes, which is most likely related with the geographic scope of the $H$. pylori strains. Another author suggests that In Thai populations, babA2 is not a biomarker for peptic ulcer disease or chronic gastritis (11). But, for strains isolated from Turkey, northern Portugal or Germany, BabA2 expression is related to the severity of gastric duodenal disorders (12, 13 and 14). $H$. pylori isolates from Cuba displayed a high frequency $(82.3 \%)$ of the babA2 allele in Cuban patients (15). Our data suggests that in Iran like some other countries the presence of $\operatorname{cag} A$ and $b a b A 2$ positive $H$. pylori strains is associated with $H$. pylori-related diseases such as chronic gastritis and there is a significant association between increased two genes together.

\section{Conclusion}

In conclusion, the cagA and babA2 genotypes might be considered as useful markers for monitoring and prognosis of NUD patients and gastric disorders in the geographic region of Iran and the presence of $H$. pylori strains with double-positive status is of high clinical relevance to $H$. pylori associated diseases.

Acknowledgements: The authors are very grateful to Amir Taher Eftekhar Sadat and all stuffs of Tabriz University of Medical Sciences Liver and Gastrointestinal diseases research center.

Ethics Committee Approval: Ethics Committee approval was received for this study from the ethics committee.

Informed Consent: Written informed consent was obtained from patients who participated in this study.

Peer-review: Externally peer-reviewed.

Conflict of Interest: No conflict of interest was declared by the author.

Financial Disclosure: The author declared that this study has received no financial support.

\section{References}

1. Marshall B, Warren JR. Unidentified curved bacilli in the stomach of patients with gastritis and peptic ulceration. Lancet 1984; 323, 1311-1315.

2. Mayerle J, den Hoed CM, Schurmann C, Stolk L, Homuth $\mathrm{G}$, Peters MJ, Völzke H, et al. Identification of genetic loci associated with Helicobacter pylori serologic status. Jama 2013; 309, 1912-1920.

3. Shaw SJ, Chen Y, Zheng H, Fu H, Burlingame MA, Marquez S, Hardy DJ. Structure-Activity Relationships of 9Substituted-9-Dihydroerythromycin-Based Motilin Agonists: Optimizing for Potency and Safety. J Med Chem 2009; 52, 6851-6859.

4. Blaser MJ. Helicobacter pylori and gastric diseases. BMJ 1998; 316, 1507-1510.

5. Ilver D, Arnqvist A, Ögren J, Frick IM, Kersulyte D, Incecik E, TBorén T. Helicobacter pylori adhesin binding fucosylated histo-blood group antigens revealed by retagging. Science 
1998; 279, 373-377.

6. Pride DT, Meinersmann RJ, Blaser MJ. Allelic variation within Helicobacter pylori babA and babB. J Immunol Infect 2001; 1; 69:1160-71.

7. Hsu PI, Hwang IR, Cittelly D, Lai KH, El-Zimaity HM, Gutierrez $\mathrm{O}$, et al. Clinical presentation in relation to diversity within the Helicobacter pylori cag pathogenicity island. Am J Gastroenterol 2002; 97: 2231-2238.

8. Aspholm-Hurtig M, Dailide G, Lahmann M, Kalia A, Ilver $\mathrm{D}$, Roche N, et al. Functional adaptation of BabA, the H. pylori ABO blood group antigen binding adhesin. Science 2004; 23; 305: 519-522.

9. Pohl MA, Romero-Gallo J, Guruge JL, Doris BT, Gordon JI, Blaser MJ. Host-dependent Lewis (Le) antigen expression in Helicobacter pylori cells recovered from Leb-transgenic mice. J Exp Med 2009; 206: 3061-3072.

10. Da Costa DM, dos Santos Pereira E, Rabenhorst, SHB. What exists beyond cagA and vacA? Helicobacter pylori genes in gastric diseases. World J Gastroenterol 2015; 21, 1056310572.

11. Chomvarin $C$, Namwat $W$, Chaicumpar $K$, Mairiang $P$, Sangchan A, Sripa B, Tor-Udom S, Vilaichone RK. Prevalence of Helicobacter pylori vacA, cagA, cagE, iceA and babA2 genotypes in Thai dyspeptic patients. Int J Infect Dis 2008; 12: 30-36.

12. Azevedo M, Eriksson S, Mendes N, Serpa J, Figueiredo C, Resende LP, et al. Infection by Helicobacter pylori expressing the BabA adhesin is influenced by the secretor phenotype. $J$ Pathol 2008; 215: 308-316.

13. Erzin Y, Koksal V, Altun S, Dobrucali A, Aslan M, Erdamar S, et al. Role of host interleukin $1 \beta$ gene (IL-1B) and interleukin 1 receptor antagonist gene (IL-1RN) polymorphisms in clinical outcomes in Helicobacter pyloripositive Turkish patients with dyspepsia. J Gastroenterol 2008; 43: 705-710.

14. Gerhard M, Lehn N, Neumayer N, Borén T, Rad R, Schepp $\mathrm{W}$, et al. Clinical relevance of the Helicobacter pylori gene for blood-group antigen-binding adhesin. Proc Natl Acad Sci 1999; 96: 12778-12783.

15. Sheu BS, Sheu SM, Yang HB, Huang AH, Wu JJ. Host gastric Lewis expression determines the bacterial density of Helicobacter pylori in babA2 genopositive infection. Gut 2003; 52: 927-932.

16. Roesler, B.M. and Zeitune, J.M.R. From Gastritis to Gastric Cancer: The Importance of Cag PAI of Helicobacter pylori on the Development of Early and Advanced Gastric Adenocarcinoma. Clin Cancer Res 2012; 224.
How to cite?

Esmaeillu M, Bahadori A, Agin M, Meral M. J Immunol Clin

Microbiol. 2016; 1(1): 10-13.

DOI: http://dx.doi.org/10.5455/jicm.5.20160514

Submit your next manuscript to the JICM and take full advantage of:

- Convenient online submission,

- Thorough peer review, Fast Response,

- No charges,

- Immediate publication on acceptance,

- Inclusion in Scopemed and High quality indexes,

- Research which is freely available for redistribution of the worldwide literature

To submit your manuscript, click on http://www.jiacm.com

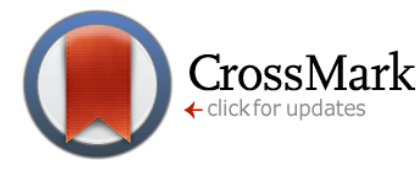

Published by The QMEL.org

International Medical Education Library

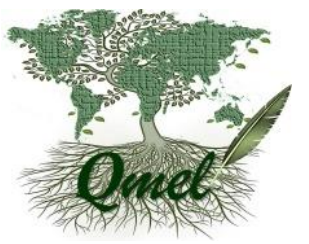

